\title{
Драматургия политического театра
}

\author{
Константин Бугров \\ Институт истории и археологии \\ Уральского отделения РАН \\ k.d.bugrov@gmail.com
}

Рецензия на книгу: Kirill Ospovat, Terror and Pity: Aleksandr Sumarokov and the Theater of Power in Elizabethan Russia. Boston: Academic Studies Press, 2016. 316 p.

Книга К. Осповата (Свободный университет Берлина) - настоящий подарок не только специалистам по истории литературы, но и всем исследователям истории общественно-политической мысли. А. Зорин, чей отзыв приведен на обратной стороне книжной обложки, называет “Terror and Pity" “самой важной работой по русской литературе елизаветинской поры со времен публикации в 1936 году прорывной книги Григория Гуковского о дворянской фронде”. С этим определением следует согласиться, добавив: в первую голову, по литературе в ее политическом аспекте.

Работа Г. А. Гуковского “Дворянская фронда в литературе” остается, на наш взгляд, одним из самых важных исследований по истории отечественной политической культуры. Ведь это Гуковский в своем новаторском анализе превратил А. П. Сумарокова в идеолога дворянской “партии” Н. И. Панина, обеспечив Сумарокову место в пантеоне российской политической мысли.

Но забудьте о Сумарокове-фрондере: в анализе К. Осповата поэт предстает вполне лояльным интеллектуалом, который своим творчеством подкрепляет политическую мифологию елизаветинского царствования. Вместе с тем, работа Осповата вовсе не ограничивается Сумароковым; в центре внимания исследователя - использование риторики “террора и милосердия”, а не творчество отдельного автора. Ожидайте многочисленных отступлений, экскурсов в историю европейской драматургии и в лабиринты политической теории - именно эти отступления и экскурсы в конечном счете и делают повествование увлекательным. Нельзя согласиться с А. Эрвингтон, в своей рецензии замечающей, что “повествование, насыщенное теорией, может быть трудным для чтения” (хотя впоследствии рецензент приходит к выводу, что внимательные читатели все-таки “будут вознаграждены”). ${ }^{1}$ Напротив, именно такой ход анализа, постоянно включающий в повествование вылазки на теоретическую территорию, вводящий новые параллели и предлагающий новые сравнения, делает книгу К. Осповата по-настоящему интригующим чтением для любого исследователя политической культуры. Методологически исследование опирается главным образом на идеи В. Беньямина о “барочной драме”; с другой стороны, Осповат широко использует и концепции М. Фуко и К. Шмитта.

\footnotetext{
${ }^{1}$ A. Ewington, Review of Terror and Pity: Aleksandr Sumarokov and the Theater of Power in Elizabethan Russia. By Kirill Ospovat (Boston: Academic Studies Press, 2016), Slavic Review, 76:3, 833-4.
} 
Что же скрыто под обложкой книги? Текст разбит на три крупные главы и эпилог (а на самом деле - еще одну, четвертую главу, просто несколько меньшего объема). Каждая из глав может читаться как отдельное эссе, хотя все они связаны между собой единством темы и последовательностью метода исследования.

В главе I, озаглавленной “Политический театр и происхождение русской трагической драмы”, автор показывает, почему, собственно, драматургия может считаться “институтом королевской власти”. По мнению К. Осповата, театральное действо демонстрировало специфические отношения между монархом и его подданными. Театр - наряду с другими формами художественного “зрелища” должен был демонстрировать спектакль “монаршей чувствительности”, реализуя своеобразную “экономику эмоций”. Театральные представления непосредственно связаны с придворной жизнью, а коль скоро эта последняя является средоточием политической жизни, то театр напрямую связан и с политикой. Впрочем, у нас правомочность характеристики драматургии Сумарокова как политического текста не вызывает даже тени сомнения.

Глава II “Хорев”: трагедия происхождения" посвящена анализу соответствующей трагедии Сумарокова. “Хорев” построен вокруг проблематизации правосудия - черты, которая, как доказывает К. Осповат, была характерной для трагедии раннего Нового времени. Таким образом, “Хорев” раскрывается и как “трагедия подозрительности”, история о преследовании невиновного по надуманным обвинениям: “Трагический театр утверждал новую роль императрицы в качестве сострадающего правителя и укреплял ее связь с подданными через коллективный опыт сострадания, одновременно поддерживая и возрождая в общественном воображении театр монаршего террора” (с. 144).

Автор обращает особое внимание на политический характер глоссария “галантной" любви; монолог Астрады в "Хореве" “отбрасывает ограничения эротической свободы как бессмысленный предрассудок, ложное мнение “света”, враждебное подлинной божественной воле, которая благосклонна к любви” (с. 111). По выходе “Хорева” В. К. Тредиаковский обрушился на этот монолог с критикой, яростно защищая “моральность банальностей” (commonplace morality), “ортодоксальное понимание врожденной моральной дисциплины, общей всем людям” (добавим от себя, что сходного взгляда на мораль придерживался в позднейших статьях и сам Сумароков). Пасторальная идиллия влюбленных, строившаяся в европейской традиции вокруг конфликтного отказа признавать родительскую власть, обладала потенциалом бунта; стандартным путем разрешения этого вопроса было “вписывание новой свободы в понятия обязанности и послушания как акт примирения, подчиняющий бунтовской потенциал и удерживающий эту свободу в рамках существующего порядка власти” (с. 112).

Наиболее обширна глава III, озаглавленная так: “Поэтическая справедливость: дворцовый переворот, политическая теология и политика зрелища в русском “Гамлете”. Здесь К. Осповат анализирует шекспировскую драму, адаптированную Сумароковым и превратившуюся на российской почве в прославление триумфа Елизаветы Петровны.

Новации Сумарокова в отношении “Гамлета” вовсе не сводятся к появлению “хэппи-энда" и здравствующей Офелии. Полемизируя с современным исследователем творчества Сумарокова М. Левиттом, К. Осповат настаивает на том, что сумароковский "Гамлет" глубоко укоренен в политическом контексте елизаветинской эпохи. 
Следуя общей рационализаторской тенденции XVIII столетия, Сумароков заменяет шекспировского призрака (“тень отца Гамлета”) на сон. Этим-то “радикальным ходом” Сумароков превращает сон Гамлета в “прозрачную метафору политического знания, в озарение насчет придворной политики и ее ужасных секретов, arcana imperii: Гамлет видит во сне лишь то, что Арманс ${ }^{2}$ рассказал ему перед тем”. В конечном счете, это секуляризует трагедию Гамлета: “С призраком или без него, “трагический” спектакль, способный “ужаснуть” человечество, на деле создается политическим кризисом, состоянием исключения, выливающимся в насильственный захват власти, переворот" (с. 159). Секуляризация такого рода, по мнению автора, позволяет вынести трагедию Сумарокова за пределы традиции официальной “политической теологии”.

К. Осповат указывает на сходства между противоречивым положением Гамлета и Елизаветы Петровны: оба не располагали законной легитимностью, однако были наделены харизмой по рождению (говоря в терминах М. Вебера). Именно с помощью харизмы Сумароков обосновывает право Елизаветы на трон, если "Гамлет" и впрямь является в данном отношении политическим иносказанием. Более того: Сумароков использует концепт героизма, который в данном случае предполагает “наличие полубожественного и полуфиктивного существа в роли отца, особый тип политического действия и особый эмоциональный тип (“отставь дела любовны”)” (с. 198). Автор продолжает анализировать “Гамлета” Сумарокова как демонстрацию “политической теологии “секуляризованной” абсолютной государственности” (с. 215), рассматривая Клавдия в параллели с лидером Верховного Тайного совета Д. М. Голицыным, который на следствии “объявлял перед судом, что когда б из ада сатана к нему пришел, то бы он хотя пред Богом и погрешил, однако ж и с ним бы для пользы своей советовал, и советов от него требовал и принимал” (с. 214). Хотя случай с обвинением Голицына и маскируется под “самоочевидную религиозную ортодоксию”, но, по мнению Осповата, речь в данном случае идет о “наказании” в смысле Фуко: “Лишь в ходе испытания подтверждается вина богохульника, и его внутреннее Я открывается судьям” (с. 215). Завершая разбор “Гамлета”, Осповат говорит о “катарсисе прощения”, одновременно обращаясь к реальному осуждению А. И. Остермана и Б. Х. Миниха Елизаветой; по словам автора, “обращаясь к внутреннему Я подданных в попытке навязать им ортодоксию повиновения автократии, составившего амальгаму с божественным правосудием, зрелище непропорционального наказания использовало эмоциональные сценарии, общие для драмы и для “театра власти” (с. 234). Иными словами, “эшафот становился моделью для жанра трагедии и отправной точкой для института придворного театра”, инструмента для контроля над публикой, “которая сама - вместе с актерами на сцене - становилась предметом испытующего царственного взгляда”.

Эпилог книги “Театр войны и мира: “чудо Бранденбургского дома” и поэтика европейского абсолютизма” посвящен изучению политических действий Петра III по отношению к разгромленной, казалось бы, Пруссии в качестве сценария “монаршего милосердия". К. Осповат интерпретирует действия Петра III в контексте европейских традиций драматургии “террора и милосердия”, доказывая,

\footnotetext{
2 Приближенный Гамлета, отсутствовавший в тексте Шекспира и введенный Сумароковым в действие пьесы.
} 
что решение остановить натиск на Пруссию было не иррациональным ходом капризного деспота, но обдуманным актом демонстрации силы через сострадание (pity). Надо добавить - политически провального сценария, несмотря на его рациональность: “Мир с Пруссией, связывавшийся с его [Петра III] любовью к германским придворным, был воспринят в основном как насилие над политическим телом [России], а не как демонстрация милосердия” (с. 271). ${ }^{3}$

В заключение нашего анализа следует обозначить несколько направлений, по которым, как нам кажется, может развиваться дискуссия (а в том, что “Terror and Pity” просто обязана вызвать дискуссию, думается, сомнений быть не должно).

Первое из них - анализ места драматургии в общей системе легитимационной литературы российского XVIII в. “Terror and Pity” выстроена вокруг уподобления политической драматургии макиавеллистским политическим трактатам, выдвигавшим на первый план “государственный интерес" и оправдывавшим нарушения христианской, цицероновской морали соображениями этого интереса: “Как и в политических трактатах Макиавелли, вновь импортированный жанр трагедии также вращался вокруг заговоров, смертных приговоров, королевской милости, раскрывая театральные эффекты действий государя" (с. XIV). Справедливое уподобление! Следует ли видеть в обвинениях по адресу Хорева в одноименной трагедии Сумарокова аллюзии на политические процессы начала царствования Елизаветы, как это делает К. Осповат вслед за Е. А. Касаткиной и Ю. В. Стенником - вопрос сложный; но сама постановка его кажется вполне оправданной.

Однако ключевой вклад в оправдание царствования новой императрицы вносили, по нашему мнению, авторы церковных проповедей и панегириков. ${ }^{4} \mathrm{~B}$ исследовании К. Осповата, конечно, обозначены связи между “Хоревом" и “Гамлетом”, с одной стороны, и формулами елизаветинских манифестов - с другой. Но в целом автор, хотя и упоминает несколько раз “официальную политическую теологию” российского XVIII в., однако не рассматривает ее детально. Это тем более интересно, что в главе III Осповат подробно анализирует использование Сумароковым в “Гамлете” концепта харизмы, позволявшего описывать Гамлета (и Елизавету?) как “героя” (с. 199). Елизавету и впрямь описывали как “героиню” с чертами античных персонажей, “новую Юдифь”, беспрестанно уподобляли ее отцу. Более того - архиепископ Платон (Малиновский) сравнил Елизавету с Христом: “Подобне нечто весь мир спасшему Христу, и Помазанница его, Наша Всемилостивейшая Государыня ЕЯ ИМПЕРАТОРСКОЕ ВЕЛИЧЕСТВО, подобне

\footnotetext{
${ }^{3}$ Отметим: непопулярность прекращения войны с Пруссией - это утверждение, присутствующее в литературе оправдания екатерининского переворота. Так, И. В. Курукин, замечая, что “политика Петра III... и сам повседневный стиль жизни монарха вызывали неизбежное отторжение головных бюрократических структур, двора и гвардии", одновременно подчеркивает: ни мир с Пруссией, ни поначалу! - война с Данией не были однозначно непопулярны (И. В. Курукин, Эпоха “дворских бурь”: Очерки политической истории послепетровской России, 1725-1762 г2. (Рязань: НРИИ, 2003), 386). Обвинения Петра III в подчинении интересов России интересам берлинского двора, столь громко звучавшие сразу после переворота, сошли на нет, как только выяснилось, что и новое российское правительство собирается ориентироваться на Берлин, а глава российской внешней политики Н. И. Панин уверен в необходимости союза с Фридрихом II.

${ }^{4}$ Е. И. Кислова, “Издание придворных проповедей в 1740-е годы” // XVIII век. Сборник 26. Cmaрое u новое в русском литературном сознании XVIII века (СПб.: Наука, 2011), 52-72.
} 
нечто во спасении Государство своего от многих бед и злоключений, нам явила и сотворила". ${ }^{5}$

По нашему мнению, анализ царской харизмы, вокруг которой была выстроена не только легитимация Елизаветы, но и поднявшийся при “дщери” в полный рост “культ" Петра Великого, предполагает все же нечто далекое от макиавеллизма. Представляется, что экстраординарные качества императрицы, о которых на все лады разглагольствовали панегиристы, уподобляют ее не ловкому и жестокому государю макиавеллистских трактатов, но (полу)божеству, ведущему подданных к общему добру и творящему одно лишь благо. Ведь и переворот в легитимационной литературе елизаветинской поры фигурирует не как захват власти (и уж точно - не как насильственный захват власти), но как чудо Провидения, в очередной раз спасшего Россию на краю пропасти. А значит, само понятие о секуляризации в политической культуре XVIII в. нуждается в дальнейшем обсуждении... Впрочем, сказанное вовсе не является упреком (нельзя ведь объять необъятное), но, думается, по этой линии можно плодотворно обсуждать и корректировать сделанные в “Terror and Pity” выводы.

Другое интересное направление - проблема представлений о власти в российском XVIII в. В анализе К. Осповата эти представления выстроены главным образом вокруг концепта террора, “жестокого спектакля власти”, который разыгрывался в драматургии (театральной и придворной) и который перетекал затем в сценарий побеждающего “сострадания”. Чрезвычайно убедительным кажется нам связь этой концептуальной модели с политической практикой императорского двора: тацитовского мира непостоянства, в котором придворные все время подвержены изменениям обстоятельств. Дальнейший анализ этой политической практики как важнейшего источника трансформаций политической мысли в широком смысле этого слова является, по нашему мнению, перспективным направлением для развития исследований. Рефлексия по поводу беспокоящего чувства нестабильности, источником которого оставалась придворная жизнь, может быть прослежена в самых разных текстах, включая и те, что выходили из-под пера влиятельнейших сановников Российской империи...

Третье направление, которое нам кажется наиболее интересным, связано с дальнейшим рассмотрением жанровой амбивалентности политической речи. В книге К. Осповата показано, каким образом Сумароков, стараясь осуществить убедительное, сильное политическое высказывание относительно характера власти Елизаветы Петровны, одновременно вынужден был перерабатывать мотивы и концепты уже сложившегося европейского художественного языка, которые, в свою очередь, обладали далеко идущей двусмысленностью. Так, пасторальная любовная идиллия способна была превратиться в язык, оправдывающий решительный бунт против устоев того, что Э. Виртшафтер именует “моральной монархией” российского XVIII в. ${ }^{6}$ Соображение о том, что адаптируемые в России новые риторические модели (а спектр их был чрезвычайно широк) открывали новые

5 Слово в день Рождения Ея Императорскаго Величества. Проповедано в Санктпетербурге в Придворной Ея Императорскаго Величества церкви Платоном Архиепископом Московским, 1750 года, декабря 18 дня (Москва: Моск. тип., 1752), 3.

${ }^{6}$ E. Wirtschafter, The Play of Ideas in Russian Enlightenment Theater (DeKalb: Northern Illinois University Press, 2003), 174 . 
возможности говорить о политике, конечно, тривиальное. Но важно, что очень часто между такой адаптацией и последующими политическими высказываниями усматривают простую каузальную связь - так, будто российские авторы заимствовали готовые доктрины, при этом уже зная заранее, в какую сторону следует их направить. Исследование К. Осповата демонстрирует, на наш взгляд, куда более точную картину трансфера: применение новых фигур выразительности приводит к скрытым внутренним конфликтам между разными риторическими ходами внутри одного текста, и на этой базе российские авторы могли договориться (или, если угодно, проговориться) до таких следствий, которых, быть может, и не предполагали те прикладные коммуникативные задачи, которые они решали в своих текстах.

Так, поиск убедительности и эффективности политической драматургии привел к тому, что в трагедиях Сумарокова внезапно оказались актуализированы те черты макиавеллистского государя, которые “официальная политическая теология" постоянно старалась исключить. Используя глоссарий работ В. Беньямина, Осповат указывает на стирание в драматургии Нового времени грани между хорошим монархом и тираном: одного не отличить от другого, если узурпатор, захвативший власть, царствует умело и успешно. Использование подобной макиавеллистской характеристики власти представляло, на наш взгляд, одну из фундаментальных проблем для российской политической мысли XVIII в., и следует согласиться с К. Осповатом в том, что характеристика эта “не только не поддавалась защите в категориях “рационального" политического дискурса, который с упорством прикидывался, будто способен отличить хорошего государя от тирана, но и в буквальном смысле не могла быть прямо высказана. <...> Лишь в непосредственном терроре и в литературном пересказе двойственная сущность суверенитета могла проявить себя, демонстрируя то, что воспринималось в качестве ее эстетического облика" (с. 283).

И впрямь: представим себе два разных риторических режима восхваления монархии - церковного панегириста в одном случае, и придворного драматурга - в другом. Коммуникативная цель у обоих авторов - единая, но средства выразительности - разные; театральное действо требует “трагического сюжета”, и в ходе его воплощения могут, как справедливо пишет Осповат, возникать двусмысленные образы власти, “противоречащие абсолютистской ортодоксии” (с. XVI). И если из придворного панегирика могли исчезнуть все намеки на насилие и жесткость (а с ними - и на всякое действие вообще, как это было, например, в пьесах Славяно-Греко-Латинской академии; по замечанию А. С. Дёмина, “действия в поздних московских пьесах нет настолько, что их можно считать большими поздравлениями коронованным монархам"7), то театральная драматургия требовала сюжета, действия, словом - “экономики эмоций”, предполагавшей, кроме прочего, “заговоры” и “перевороты” в духе Макиавелли. Подобный подход кажется нам продуктивным - может быть, наиболее продуктивным из всех имеющихся на сегодняшний день - для изучения отечественной политической культуры.

\footnotetext{
7 Дёмин А. С. О художественности древнерусской литературы (Москва: Языки русской культуры, 1998), 516.
} 